\title{
A FELSŐOKTATÁS JÖVŐJE, AZ ÉLETHOSSZI TANULÁS ÉS A GLOBÁLIS KIHIIVÁSOK
}

\section{FUTURE OF HIGHER EDUCATION, LIFE-LONG LEARNING AND GLOBAL CHALLENGES}

\author{
Simai Mihály \\ az MTA rendes tagja, kutató professor emeritus, egyetemi tanár \\ MTA Közgazdaság- és Regionális Tudományi Kutatóközpont Világgazdasági Intézet \\ mihalysimai@gmail.com
}

\section{ÖSSZEFOGLALÁS}

A munka jövőjét formáló tudományos, technikai és gazdasági erők és folyamatok összekapcsolódnak az oktatási rendszerek alakulásával, melyekben a 21. században meghatározó fontosságúvá vált a felsőoktatás. Új és gyorsan változó demográfiai, társadalmi, geopolitikai, geoökonómiai, tudományos, technikai környezetben alakulnak és bővülnek a "harmadik szint" fejlődésének hagyományos tényezői. Világszerte tovább nő az egyetemek és a hallgatók száma. Differenciálódik és nemzetközivé válik az intézményrendszer. Lényeges probléma, hogy az oktatás tartalmi és szervezeti fejlődése túl lassan igazodik a gyorsan változó társadalmi és gazdasági igényekhez és az élethosszi tanulás követelményeihez.

\section{ABSTRACT}

The scientific, technological and economic forces and processes which are influencing the future of work are interconnected with the development of the educational systems. Higher education became the decisive institution in its framework in the $21^{\text {st }}$ century. New and rapidly changing forces and factors in demographic, social, geopolitical, geoeconomic, scientific and technical environment are shaping and expanding the traditional factors of the development on the "third level" of the system. The worldwide increase in the number of universities and of the students is accompanied with the differentiation and internationalization of the system. The too slow progress in the content and institutional changes and in the adaptation to the needs of social and economic requirements and the demands of lifelong learning however comprise major problems.

Kulcsszavak: munka, felsőoktatás, élethosszi tanulás, egyetemek, hallgatók, demográfia, tudomány, társadalom, gazdaság, mesterséges intelligencia, geopolitika

Keywords: work, higher education, lifelong learning, universities, students, demography, science, society, economy, artifical intelligence, geopolitics 
A történelem olyan társadalmak temetője, amelyek nem voltak képesek vagy hajlandók alkalmazkodni a fejlődés változó követelményeihez. Az emberi tényezőknek s különösen az emberek képességeinek és ezek fejlődésének a közvetlenebb és szélesebb környezetük nyújtotta lehetőségek hasznosítására, illetve a különböző válsághelyzetek kezelésére döntő szerepük volt az alkalmazkodásban, illetve annak elmaradásában. Az elmúlt néhány évszázadban fokozatosan nőtt a képességek formálódásában az oktatási rendszer szerepe, szorosan kapcsolódva az államok fejlettségi szintjének és a társadalmak szükségéleteinek alakulásához.

A 21. század versengő világában, a folyamatban központi jelentőségű felsőoktatás, amelynek bővülő hálózatai és differenciálódó intézményei növekvő fontosságúak tudományos ülésünk „rendező témájának”, a munka jövőjének alakításában. Ezek intézményei az egyes államokban a gazdasági és társadalmi feltételekbe ágyazódva számos területen sajátosan fejlődnek. Előadásomban azokkal az általánosítható, főbb globális kihívásokkal és trendekkel foglalkozom, amelyek szerepét különösen jelentősnek tartom a felsőoktatási rendszerek jövőjének alakításában.

Hosszú történelme során a felsőoktatás fejlődésére két, gyakran egymással ellentétes tényező hatása volt különösen lényeges, az egyik a társadalmak szükségleteinek alakulása, a másik a törekvés a múlt eredményeinek és a kialakult intézményi formáknak konzerválására. A 20. század második felében, döntően külső kényszerítő erők hatására, a felsőoktatásban jelentős átalakulás kezdődött. Az elitegyetemek mellett vagy itt-ott azok átalakulása nyomán megjelentek és gyorsan bővültek a tömegegyetemek. Az ún. elitegyetemek, vagyis a hagyományos ,elefántcsonttornyok" közül egyre több került szerves kapcsolatba a gyakorlati élettel, illetve annak szükségleteivel. Négy húzóerő játszott ebben különösen fontos szerepet. Az egyéni igények változása volt az egyik. Az egyetemi diploma megszerzése a társadalmi mobilitás fontos eszközévé vált a társadalmak alsóbb rétegei számára, különösen olyan államokban, ahol erre az anyagi viszonyok lehetőséget adtak. A másik húzóerő az új, magas képzettségű szakemberek iránti igények igen gyors növekedése volt, nemcsak a gazdaságban az új szektorok kibontakozása és a régebbiek technikai átalakulás nyomán, hanem a kutató és fejlesztő tevékenységekben, a hadseregekben és bizonyos fokig az államapparátusban, és természetesen az oktatási rendszerben. A harmadik az államok szerepének megnövekedése volt az oktatási rendszerben, követve a társadalmi szükségleteket. A jóléti államok pedig az egyéni igények kielégítését is segítették. A negyedik tényező a nemzetközi hatásokkal függött össze. A dekolonizáció nyomán gyakorlatilag mindegyik új állam egyetemek alapítására, illetve a működő felsőoktatási intézmények fejlesztésére és modernizálására törekedett (Simai, 1992).

A 21. században nemcsak a hagyományos tényezők váltak intenzívebbé, új tényezők miatt is döntő feltétellé vált, hogy a felsőoktatási intézmények alapítói és fenntartói, menedzserei és professzorai, szolgáltatásaiknak megrendelői, a hall- 
gatók, illetve más felhasználók minden korábbinál és más intézményeknél átgondoltabban, nagyobb mértékü jövőorientáltsággal döntsenek és cselekedjenek. Az egyetemek esetében különösen lényegessé váltak a hosszabb távú és átfogó stratégiai döntések az oktatásban, a tanulásban és a tudományos kutatómunkával kapcsolatos témákban.

A távolabbi jövőt, húsz-harmincéves távlatokat figyelembe véve a jelenlegi helyzetben döntők azok a kritikus trendek, amelyekre a felsőoktatási intézményeknek fel kell készülniük.

A 21. század jelenlegi szakaszában a felsőoktatás szemszögéböl különösen jelentősek a demográfiai, társadalmi, geopolitikai, geoökonómiai, technikai, geoökológiai transzformációk következményei. Ezek mindegyike külön-külön, összességükben pedig halmozottan hatnak a felsőoktatás jövőjére. Transzformációknak tekinthetők az olyan mennyiségi és minőségi változások, amelyek átalakítják az adott rendszert, annak szerkezetét, müködését vagy más rendszerekre gyakorolt hatásának következményeit. Ezek a folyamatok ritkán szervezettek vagy tervezhetők elöre. Közös jellemzöjük, hogy ha a társadalmak ezekre nem vagy nem megfelelően válaszolnak, súlyos zavarokkal, esetleg válságokkal kerülhetnek szembe. A transzformációkkal kapcsolatos problémák kezelése megköveteli a rugalmas, alkalmazkodni képes oktatáspolitikát és a nyitott vezetést (Simai, 2016).

A globális geopolitikai transzformáció komplex folyamatának a felsőoktatással kapcsolatos következményei csak nagy általánosságban prognosztizálhatók. Az államok számának további növekedése, a gazdasági és katonai-politikai hatalmi viszonyok alakulása nyomán többpólusúvá váló világ államközi kapcsolatrendszerének átalakulása, az államok belső társadalmi, politikai rendszerében végbemenő változások, új konfliktusforrások megjelenése a hagyományos megoldhatatlan problémák mellett áttekinthetetlen káoszt valószínüsítenek. Az nyilvánvaló, hogy ebben a világban a versengés és az együttműködési kényszer egyidejüleg érvényesül, de nem szükségképp azonos erősséggel. A versengésben az emberi erőforrások nagy szerepe miatt jelentős tényező marad a felsőoktatás. Ez is szerepet játszik a felsőoktatás igen gyors fejlődésében például Ázsiában és Afrikában. Az államok keretei közötti vallási, etnikai és más eredetủ konfliktusok sem fogják elkerülni az oktatási rendszert s különösen nem a felsőoktatást. Ideológiai szempontból ebben jelentős szerepük marad a vallási szervezetekhez és eszmékhez közvetlenül kötődő egyetemi hálózatoknak. Ez a Közel-Keleten az iszlám egyetemek, másutt a katolikus vagy hindu egyetemek szerepének alakulásában jut kifejezésre. A jelenlegi mintegy hatvan diktatórikus rendszerủ állam mellett szaporodnak a demokratikus játékszabályokat formailag érvényesító tekintélyuralmi berendezkedések. Ezek szerepe tovább gyengíti az egyetemek történetében oly nagy szerepet játszó akadémiai szabadságot s különösen ennek gyakorlati érvényesíthetőségét. (Az egyetemi autonómiának négy dimenziója a 
szervezeti, pénzügyi, személyzeti és oktatási; a korlátozások következményei természetesen nem azonosak.) Az egyre zavarosabb, kaotikusabb és konfliktusosabb világban azonban nemcsak a diktatórikus tekintélyuralmi rendszerekben fenyegetik növekvő veszélyek az akadémiai szabadságot, hanem egyes demokratikus államokban is. Sajátos probléma lett a felsőoktatást általában negatívan érinto olyan, az angol nyelvben ,post truth”, magyarra fordítva ,igazság utáni” állami döntési rendszerek szaporodása, amelyekben nem tények és realitások, hanem feltételezések, elöítéletek és az általuk manipulált közvélemény hangulatára való hivatkozások vezetik a döntéshozókat.

A demográfiai transzformáció elsődleges, közvetlen hatása a felsőoktatás jövőjére hagyományosan a tizenöt-huszonnégy év közötti korcsoport nagyságának alakulásával kapcsolatos. Ennek aránya a világ népességében 2017-ben 16\% volt, és pár évtizedig még gyorsabban nő a Föld lakosságánál. A következő évtizedekben leggyorsabban Afrikában bővül. A 21. század ötvenes éveire azonban mindenütt lassul a növekedése. Erre az időre azonban két további probléma válik döntőbbé. A világ a jelenleginél sokkal zsúfoltabb lesz, s évszázadunk közepe táján közel tízmilliárd emberrel kell megosztani a bolygónkat. Ezek több mint $90 \%$-a a jelenlegi fejlődő vagy a közepes fejlettség alsóbb csoportjába tartozó államokban él majd, túlnyomóan városokban. Ez növeli a tömegegyetemek jelentőségét, ugyanakkor területileg és minőségileg tovább differenciálja a felsőoktatási rendszert. A foglalkoztatás kérdésköre demográfiai szempontból is komplexebbé válik. Az ENSZ demográfiai statisztikáira épült becsléseim szerint századunk húszas éveinek közepéig naponta mintegy 25000 fiatal lép a munkaképes korba. A lakosság átlagos életkora tovább emelkedik. Ez egyrészt annak következménye, hogy a hatvanöt évesnél idősebbek száma a Föld lakói növekedési rátájának kétszeresével nő, másrészt a különböző szociális szolgáltatásokkal kapcsolatos igények is gyorsan növekednek, ami valószínúleg nagyobb mértékben fogja versenyeztetni az igényeket az oktatási rendszerre fordított kiadásokkal (UN, 2017). A további demográfiai és szociális problémák között valószínünek látszik, hogy évszázadunk közepe táján még mindig kb. százmillión felüli lesz azok száma, akik nem jutnak elemi oktatáshoz és különösen nem középiskolához, illetve azt nem fejezik be. Sok százmillió fiatal föleg anyagi okokból nem kerül be a felsőoktatásba. Az oktatásban való megnövekedett részvétel nyomán a föld lakói ugyanakkor sokkal iskolázottabbá válnak. A jelenleg világméretünek valószínüsített munkahelyhiány egyik döntő tényezője lehet a kivándorlás ösztönzésének, s a nemzetközi vándorlásnak.

A munka jövője szempontjából, a demográfiai és gazdasági problémák összekapcsolódása nyomán a felsőoktatás jövőjét befolyásoló transzformációk egyik döntő területe a tudásalapú társadalom kibontakozása. Az UNESCO ezzel kapcsolatos átfogó tanulmánya szerint (UNESCO, 2005) a tudásalapú társadalom egy olyan, sajátos, tudomány vezérelte fejlődési foka a kapitalizmusnak, amely a tudásra épül. A tudásalapú gazdaság és társadalom olyan képződmények, ame- 
lyekben a tudás termelése, felhalmozása, szétterülése és hasznosítása jelentik a legfontosabb hozzájárulást a termelékenység növeléséhez, a hatékonyság javításához, az életfeltételek, egészségügyi viszonyok jobbá tételéhez, a gazdasági és politikai hatalom erősítéséhez. A jelenlegi fejlődési szakaszban egyik kulcsfontosságú folyamat a digitalizálódás hatása a felsőoktatási rendszerekre. Egyik, igen fontos kérdéscsoport a felsőoktatás szerepe ennek folyamatában, illetve a folyamat hatása a felsőoktatásra. A társadalomnak és különösen a fejlödésben döntő szerepet játszó rétegeknek magas szintű felkészültséggel kell rendelkezniük a gyorsan bővülő hatalmas információs és tudástömeg befogadására, feldolgozására, megfelelő értékelésére. Kreatív módon kell válaszolniuk az egyének, a társadalom és különösen a munka világa rövidebb távú új igényeire. Meghatározott mértékủ politikai és társadalmi felelősséget kell vállalniuk az egész oktatási rendszer fejlődésének irányáért és minőségének javításáért. Hozzá kell járulniuk a tudás termeléséhez, a társadalom kultúrájának fejlődéséhez, a felnőttek oktatásához, a tudásra épülő társadalmi mobilitás elősegítéséhez. Ezek figyelembevételével kell központi fontosságúnak tekinteniük oktatási tevékenységüket, hallgatóik jobb felkészítését egy hatékony életvitelre a változó világban.

Egyik igen lényeges kérdéssé vált, hogy a világon az elmúlt évszázad során megsokszorozódott, a társadalmi és gazdasági fejlődés szempontjából hasznos tudást és tapasztalatot, amely évről évre tovább bővül, miként adja át az oktatási rendszer a tanulóknak. Ezzel a kihívással mindeddig nem tudtak megküzdeni sem a fejlett, sem a kevésbé fejlett államokban. Csak igen lassan alakul ki az új munkamegosztás az oktatási rendszerekben az alapszint, a középszint alsó és felső szakasza, valamint a felsőoktatás szintjei között. A tudományos és műszaki fejlődés előmozdításában, az államok gazdasági felemelkedésében a 21. században a felsőoktatás szerepe vált döntő fontosságúvá.

A technikai fejlődés és a társadalmak életviszonyainak változásai nyomán már néhány évtizeddel ezelőtt megjelentek a tudásalapú fejlődés követelményei és következményei a munka világában. Folyamatosan változik a „funkcionális írástudás" tartalma. A régi szakismeretek a korábbi korokhoz képest sokkal gyorsabban avulnak el, vagy tartalmuk módosul jelentősen. Új, korábban ismeretlen szakmák tömegei jelennek meg, amelyek kifejlesztésében az iskolarendszernek és a gyakorlatnak egyaránt jelentős a szerepe. A felsőoktatás terjedése, a végzettek számának növekedése és a tudományos ismeretekhez való hozzáférhetőség digitális eszközeinek globális terjedése nyomán a magas képzettségü munkaerőre épült versenyelőnyök a következő évtizedekben lassan elhagyják a fejlett világot. Szükül a fejlett államok minőségre és versenyképességre épült előnye is. Az éles globális versenyben a fejlett országok magasan képzett szakembereinek helyzete attól is függ, hogy milyen mértékben és mennyire tartósan képesek olyan feladatok gyors és hatékony végrehajtására, melyeket külső versenytársaik még nem tudnak olcsóbban és hatékonyabban elvégezni. Ebben a helyzetben nemcsak sú- 
lyos hiba, hanem nemzeti öngyilkosság a 20., sőt akár a 19. századbeli inasképzést tekinteni a hazai szakmunkásképzés példaképének. Az okos és tanulóképes államok igyekeznek elkerülni, hogy a kibontakozó tudásalapú társadalomban a történelem rossz oldalára kerüljenek, ahonnan felkapaszkodni rendkívül nehéz.

A felsőoktatás iránti kereslet valamennyi országban a jövőben tovább diverzifikálódik. A fejlett államokban döntően a tanítás, kutatás és innováció ún. tudásháromszögében betöltött szerepe marad a fö tényező. Ez jelentős mértékben ösztönzi a minőségi változások előmozdítását. Ezekben az országokban is igen fontos tényező marad azonban annak biztosíthatósága, hogy a társadalom minél szélesebb rétegei számára váljon lehetővé a részvétel a felsőoktatásban. Ez egyébként egybevág a fejlődésorientált célokkal és a társadalmi-gazdasági érdekekkel (Simai, 1998).

Elsősorban az egyetemek és a hallgatók gyorsan növekvő száma tükrözi globális méretekben az államok, a vállalatok és az egyes emberek érdekeltségének alakulását a felsőoktatás mennyiségi fejlesztésében.

A 21. század második évtizedének közepén a bolygón 203 országban, illetve önkormányzattal rendelkező területen közel 22000 felsőoktatási intézmény müködött. Globálisan a felsőoktatásban részt vevők aránya az adott korcsoportban gyorsan nőtt. Az 1970-es évek elején mintegy huszonhét millió, a 90-es évek elején pedig csaknem kilencvenhét millió diák tanult a világ tízezer néhányszáz felsőoktatási intézményében. Eddig a tömegméretűvé vált felsőoktatás a világ fejlett térségeiben lényegében biztosította a modern fejlődéshez szükséges emberi erőforrásokat. Nőtt azonban a szakadék a társadalmi igények változása és a felsőoktatás szerkezeti viszonyai között. Az UNESCO becslései szerint egy évtizeden belül megkétszereződik az egyetemi hallgatók száma a fejlett világon kívüli államokban. 2025-re a felsőoktatás képességét úgy kellene fejleszteni, hogy több mint 260 millió hallgatót szolgáljon ki, a 2017-es 158 millióval szemben (UNESCO, 2017). Figyelemre méltó a fejlődő országok gyors felzárkózása is. Ez tovább növeli a magasan képzett szakemberek kínálatát, akik ráadásul sokkal olcsóbbak is, mint a fejlett államokbeli kollégáik. Ázsia ebben is élen jár. Kínában már ma is magasabb az egyetemi hallgatók száma, mint az USA-ban, s a különbség tovább nő. Hasonló növekedés megy végbe Indiában is. Valószínü, hogy az oktatás minősége a legtöbb esetben alacsonyabb, mint az USA-ban vagy Nyugat-Európa egyetemein, az a tény azonban, hogy Ázsia több mint kétszer annyi mérnököt „termel”, mint Amerika és Európa együttvéve, a minőségi különbségek ellenére is lényeges tényező a globális versenyben. Figyelemre méltó az is, hogy Indiából és Kínából évente több százezer diák tanul külföldi egyetemeken. Döntő többségük Észak-Amerikában, Angliában és Németországban, valamint Ausztráliában. Az USA-ban a müszaki tudományokban, matematikában és informatikában doktori címet szerzők közel fele külföldi, föként kínai, indiai, dél-koreai és arab. Hasonlóak az arányok Nagy-Britanniában is. 
A tudásalapú társadalom kibontakozásának egyik fontos következménye és elősegítője a felsőoktatás nemzetközivé válása. Ez egyrészt a tudomány nemzetköziesedéséhez kapcsolódik, amelyben igen jelentős a felsőoktatási intézmények szerepe. Nem lényegtelenek azonban az üzleti meggondolások sem. A felsőoktatás a 21. századra ugyanis nemcsak a tudás terjesztésének döntő eszköze, hanem hatalmas üzleti vállalkozás is. A nemzetközivé válás folyamatát jelzik a felsőoktatási intézmények nemzetközi szövetségei és az integrációs szervezetek szerepének megnövekedett fontossága, a kutatási programok finanszírozásának és végrehajtásának nemzetköziesedése, a külföldön tanulók számának növekedése, az oktatószemélyzet külföldi kutató és tanári tevékenysége, egyetemek külföldi fiókintézményeinek kiépítése, a külföldre bérbe adott oktatási programok számának szaporodása, a távoktatás nemzetközi terjedése. Mindez nemcsak a felsőoktatási intézmények együttmüködését, hanem a köztük kibontakozott verseny nemzetközivé válását is növelni fogja a jövőben. Azonban egyes, ezzel szemben ható tendenciák erősödése is megfigyelhető, föleg néhány fejlett országban.

Az eddigiekben említett tényezők hatásainak erőssége a világ egyes térségeiben és államaiban eltérő. Különböző az államok és az intézmények képessége és készsége is a reagálásra. Mindezek tovább differenciálják a felsőoktatás szervezetét és szerkezetét. Állami költségvetésből finanszírozott túlzsúfolt „diplomagyárak”, „olcsó" és alacsony színvonalú kis helyi egyetemek vagy föiskolák, specializált, magas szakmai felkészítést biztosító egyetemi szintü ,iskolák”, nagy tekintélyü kutatóegyetemek, amelyek az államok kutató-fejlesztő központjai, egyetemeket, állami kutatóintézeteket és magánvállalatokat magukba foglaló szakmai szövetségek már jelenleg is igen változatos képet rajzolnak ki a felsőoktatás intézményeiről. Lényeges differenciáló tényező a tulajdonosi háttér és az intézmények nemzetközi jellege és mértéke is. A differenciáló tényezők negatív hatásai leginkább az oktatás minőségében jutnak érvényre. A fejlődő országok sok helyi egyeteme kénytelen pénzügyi okokból vagy oktatóinak szakmai gyengesége miatt a világ tudományának fó áramlataitól elszigetelten müködni. Ez is szerepet játszik a megszerzett diplomák értéke közötti eltérésekben. Ez egyébként növekvő feszültségforrássá válik. Korszerütlen, meghaladott oktatási program és az új befogadását előmozdító gondolkodás hiánya persze nem csak a kevésbé fejlett államokban probléma.

Valószínủ az is, hogy a felsőoktatásban való megnövekedett részvétel nyomán olyan országokban, ahol a képzés szerkezete irracionális, s amelyek nem képesek megfelelő munkahelyeket biztosítani, még hosszú ideig szélesedni fog az ,állástalan diplomások” vagy „diplomás proletárok” köre. Ez a probléma egyébként már ma is egyik tényezője a kivándorlás ösztönzésének s a nemzetközi migrációnak.

Két igen fontos további tendencia válik a jövőben intenzívebbé. Az egyik a virtuális egyetemek szaporodása, a másik a nagyvállatok keretében létrehozott, erősen szakosított, az adott társaság emberi erőforrásainak fejlesztését szolgáló, esetenként speciális diplomát is adó felsőfokú intézmények. A virtuális egyetemek szaporodá- 
sában az információs-kommunikációs technikai fejlődés és a felnőttoktatás szükségletei játszanak döntő szerepet. Ez az intézménytípus játszik jelentős szerepet az élethosszig tartó tanulás elősegítésében is. A fentiekkel összefüggő lényeges tendenciát képviselnek az egyetemi hallgatók korösszetételében végbemenő változások. Csökken a hagyományos középiskola-egyetem-munkahely útvonalon haladók aránya, és nő azoké, akik az egyetemi éveik alatt már dolgoznak, Amerikai adatok szerint egy átlagos egyetemi hallgató heti tizenkilenc-húsz órát dolgozik. Az OECD államokban a felnőtt lakosság $40 \%$-a vesz részt valamilyen formális vagy nem formális képzésben, $\mathrm{s}$ egy adott évben a távoktatásban részt vevők átlagos életkora harmincnégy év volt. A fejlett államok huszonnégy óriásegyetemén több mint egymillióan vesznek részt távoktatásban. A következő évtizedekben világméretekben is bővülni fog, s változatosabbá és rugalmasabbá válik az ilyen intézmények köre. A világ egyes nagyobb térségeit kiszolgáló többnyelvű egyetemek, transznacionális felsőoktatási vállalkozások válnak a távoktatás fontos centrumaivá. Globalizálódik az egyetemeket kiszolgáló munkaerő piaca is. Meg kell jegyezni, hogy a virtuális egyetemek és a távoktatás intézményeinek szaporodása a megbízható akkreditáció hiányában melegágya lehet az álegyetemek terjedésének.

Az oktatás tartalmával, illetve ennek változásaival kapcsolatos előrejelzések érdemben és mélyebben általában egy-egy szakterületen értelmezhetőek. Általános megjegyzésként szükséges azonban kiemelni, hogy a felsőoktatásnak a jövőben is valamely adott szakterület számára kell szakembereket képeznie. Központi feladata marad a magas szintü szakemberképzés, s ennek keretében az adott szakterületek történelmi, elméleti és gyakorlati technikai összefüggéseinek és tendenciáinak oktatása. Ezt azonban jövőorientáltan, de a jelennel összevetve kell megtennie, betetőzve a megelőző oktatási-képzési fázisokat, és fel kell készítenie a hallgatókat a posztgraduális képzésben való részvételre is. Tekintetbe kell vennie az egyetemi szintet követő továbbképzést, és az oktatás tartalmát illetően is fel kell készülnie az egész életen át szükséges tanulásban betöltendő növekvő szerepre. Ezért is téves és hibás az olyan, s Magyarországon is teret hódító felfogás, amely a felsőoktatási intézmények szerepét a szűken értelmezett szakképzésre és a munkaerőpiac rövid távú szükségleteinek kielégítésére korlátozná. Nő a felsőoktatás társadalmi szerepe az egyes államok és térségek kulturális színvonalának emelésében is. Társadalmi katasztrófákhoz vezethet, ha kényszerből vagy opportunizmusból feladják hosszú távú, a tudományok átfogó átadásával és a társadalmak szellemi fejlődésének elősegítésével kapcsolatos feladataikat.

Az ún. „központi kompetencia” egyébként egyre szélesebb ismereteket követel. Az új információs forradalom korában bővül a szükséges ismeretek köre és az ún. új írástudás igénye ahhoz, hogy valamely szakterületen dolgozók megkeressék, tárolják és alkalmazzák az új információkat, az új tudást és tapasztalatokat. Négy területet emel ki a szakirodalom: a kommunikációs „,́rástudást”, a tudományos „,́rástudást”, a társadalmi „,irástudást” és az ökológiai „,irástudást”. Ezek termé- 
szetesen nemcsak a szakmák, hanem az emberi magatartások formálódása szempontjából is lényegesek.

A felsőoktatás jövőjét illetően a helyi feltételek és lehetőségek természetesen különbözőek maradnak. Megfogalmazható azonban néhány olyan célkitüzés, amellyel kapcsolatban lényegében általános egyetértés alakulhat ki általában $\mathrm{s}$ különösen a munka jövőjének alakításában játszott szerepével kapcsolatban:

- bővíteni kell a felsőoktatáshoz hozzájutók körét annak érdekében, hogy a lakosság sokkal szélesebb rétegei kerülhessenek a felsőoktatásba a fejlődő világban és a fejlett államokban;

- növelni kell azok számát, akik a felvettek közül el is végzik az egyetemet;

- az állami támogatás és az intézmények hatékonyságának növelésével csökkenteni kell a felsőoktatásban való részvétel költségeit a hallgatók számára;

- a társadalmak szükségleteinek, az új tudományos ismeretek fejlesztésének, terjesztésének és a munka jövőjével kapcsolatos igényeknek figyelembevételével sokkal rendszeresebben, átgondoltan és összehangoltan kell korszerüsíteni a képzés szervezetét és tartalmát;

- a felsőoktatási intézményeknek jelentősebb szerepet kell játszaniuk, s ehhez jobban fel kell készülniük az egész életen át tartó tanulás igényeinek kielégítésére.

\section{IRODALOM}

Simai M. (1992): The Society and the Universities. The First Richard A Harvill Conference on Higher Education. The Universities of the Future: Roles in the Changing World Order. Conference Proceedings. Tucson: University of Arizona, 61.

Simai M. (1998): Are the Global Employment Problems in the 1990s Menegeable? In: Ronning, A. H. - Kearney, M.-L. (eds.): Graduate Prospects in a Changing Society. Paris: UNESCO, 43-63.

Simai M. (2016): A harmadik évezred nyitánya. Budapest: Corvina Kiadó, 21-28.

World Employment Confederation (2016): The Future of Work Issues at Stake and Policy Recommendations from the Employment Industry. Brussels: WEC, http://changingworld. work/ wp-content/uploads/2016/09/White-Paper-Executive-Summary_FINAL-1. pdf

UN - United Nations Department of Economic and Social Affairs Population Division (2017): World Population Prospects: The 2017 Revision, Key Findings and Advance Tables. ESA/P/ WP/248. New York: UN, https://esa. un. org/unpd/wpp/Publications/Files/WPP2017_KeyFindings. pdf

UNESCO (1995): Policy Paper for Change and Development in Higher Education. Paris: UNESCO, http://unesdoc. unesco. org/images/0009/000989/098992e. pdf

UNESCO (2005): Towards Knowledge Societies. Paris: UNESCO, http://unesdoc.unesco.org/ images/0014/001418/141843e. pdf

UNESCO Global Forum on Rankings and Accountability of Higher Education (2017): Uses and Misuses of Rankings in Higher Education. Conference Paper. Paris: UNESCO Publishing, http://unesdoc.unesco.org/images/0022/002207/220789e. pdf 